\title{
WORSHIP FACILITY IMPROVEMENT IN KELURAHAN SEI KERAH HILIR I KECAMATAN MEDAN PERJUANGAN, KOTA MEDAN
}

\author{
Lindarto, D. ${ }^{1)}$, Harisdani $\mathrm{DD}^{2)}$ \\ ${ }^{1)}$ Department of Architecture, Faculty of Engineering, Universitas Sumatera Utara \\ Email: dwi.lindarto@usu.ac.id \\ ${ }^{2)}$ Department of Architecture, Faculty of Engineering, Universitas Sumatera Utara \\ Email: devin.defriza@usu.ac.id
}

\begin{abstract}
Have been done community service activities such as the identification and provision of facilities requiring increased to accommodate Islamic religious activities, community involvement as a partner with which the Badan Kemakmuran Masjid (BKM) Serikat Amal Baik Mosque and SDIT Zahira school in Kelurahan Sei Kera Hilir I Kecamatan Medan Perjuangan, Kota Medan. Succession of transfer of energy-saving knowledge and training within the framework of Islamic spiritual education development in a sustainable manner. The concept of education link and match between the world of education with the implementation of direct education (practice) on the field is done in this activity by linking (linkage activity method) between SDIT educational activities by utilizing as part of religious practice is a real education. The result of this increase in worship facilities helped accommodate the nation's next generation of Islamic worship activities, SDIT Zahira students joined the surrounding community in an effort to promote the prosperity of Islam as well as preserving the architectural artifacts of the Amal Good Union mosque as the identity and landmark of Gang Sado, Medan.
\end{abstract}

Keywords: Worship Facilities, Identity and Region Landmark, Link and Match of Islamic Education

\section{INTRODUCTION}

One indicator of the progress of the construction of the so-called urban areas livable city [1], is the implementation of spiritual worship activities are reflected in the availability of facilities and comfortable atmosphere of the house of worship, religious, complete facilities and beautiful and able to accommodate the ongoing religious activities. Medan in development to the metropolitan city in line with the increase in community activities prioritized building houses of worship as one of the city's infrastructure development goals and forming a religious identity cultured city. One subdistrict of Medan populous is the district of Medan struggle with a population of some 100,000 inhabitants [2]. Such a population is very significant with the number of places of worship that must be available in accommodating Muslim worship activities in the area's community.

Kelurahan Sei Kera Hilir I Sub Terrain Struggle is a region famous old city in Serdang area of Medan. In this area there are road Umar Ibrahim, popularly known as the Gang Sado. The Gang Sado region is an area of dense mixture of traditional settlement and settlement of migrants. In the development of regional development are quite high population growth in the area of Gang Sado require increased religious facilities, especially of worship for Muslims. Medan City government policy in this regard is the increase of new facilities and the local mosque mosque mosque which has a mainly historical and cultural heritage value of assets as an identity and town conservation area [3]. Gang Sado contained in one simple old mosque is Serikat Amal Baik Mosque, 
Lindarto. et.al. Worship Facility Improvement In Kelurahan Sei Kerah Hilir I Kecamatan Medan Perjuangan, Kota Medan

located at Jalan Ibrahim Umar Gg.Nikmat No. 7 .

Surrounding communities are very familiar with these places of worship as a regional landmark, as houses of worship heritage and identity that has potential important in the development of the Sei Kera Hilir I territory (known as Musholla Gang Sado Serdang). Routine religious activities such as praying five times a growing congregation in addition to activities and teaching perwiridan afternoon routine performed by BKM with enthusiasts and especially for lectures attended by mothers and children in the maghrib study lively forum.

Means mosque facility with the growing religious activities indicates inequality. Seen during the month of Ramadan, the mosque was noticeably lacking facilities for the comfort of worship piously, that can affect the formation of generations of Islam [4]. Observing the inequality of the perceived need for facilities to improve the facilities and infrastructures of worship in the mosque to accommodate the activities of Islamic worship.

Location of the mosque is adjacent to the facility early childhood education and SDIT Zahira school. Within the framework of the development of education spiritual Islamic ongoing basis the educational concept of link and match between the world of primary education [5] with the application of direct education (practice) on the field is done in service activities is by linking (linkage activity method) [6] Among the educational activities SDIT with Amal mosque utilize either as part of religious practice is real education. During this time SDIT Zahira students who use the school hall as a means of education of worship (prayers, etc.) will be redirected to worship directly with civilized practice guidance in this regard at the same mosque as an attempt to enliven the Serikat Amal Baik mosque.

\section{METHOD OF EXECUTION}

This community service activities in collaboration with the partner BKM Serikat Amal Baik mosque and Zahira SDIT school at Sei Kera Hilir I as the coordination efforts inclusion of community participation facility users. Strengthening social capital by three parameters of social capital [7] trust, norms, networks, is the object of community service performed between the Universitas Sumatera Utara, in this case together with a team from the Department of Architecture with the community by identifying the facilities and infrastructure of worship that requires care and increase the involvement of community participation [8] (BKM mosques and schools SDIT Zahira).

Method of implementation of this devotion is the identification of some of the facilities of the mosque which will be facilitated by this community service activities. Identification will be done by observing the mosque [9] and discussions with BKM take place where the mosque is in Sei Kera Hilir I Medan. With the agreement and approval of the BKM and the SDIT Zahira School marked by the signing of a statement of willingness to cooperate, then the implementation of service can be done in fiscal year 2018 with the signing of devotion between the Chairman of the Team to the Chairman of the Institute for Community Service (LPM) USU done.

The initial phase of the implementation is done by actual survey existing conditions of mosque building facilities. The results of the observation will be used as the data for the improvement of places of worship, and then make the provision of facilities and knowledge transfer and training of energy saving within the framework of Islamic spiritual education development in a sustainable manner. Then community service team produced a final report on the activities of accountability for the implementation of activities. 


\section{RESULTS AND DISCUSSION}

In this community service target is the infrastructure facilities of worship Serikat Amal Baik mosque managed by BKM community in the Kelurahan Sei Kera Hilir I Kecamatan Medan Perjuangan. Physical Target field is the improvement of facilities for supporting a comfortable worship. Target activities is the involvement of student activities at SDIT Zahira school to include a mosque as part of religious education means creating prosperity of this mosque achieve healthy religious community and energy saving [10].

In proposing the activities, as the outcome is a service, product / goods and articles. For the output of services is the training / simulation associated with destination's activities and outputs of products / goods, related to the procurement of goods and equipment related results service activities. For superficial article, the proposer will make reports and articles related to the implementation and findings on the implementation of service activities which is written as a article.

Community service activities are focused on the increase of Serikat Amal Baik Mosque facilities in the Kelurahan Sei Kera Hilir I as follows, first, is a physical identification mosque facilities. Second, is assisted in the provision of infrastructure facilities / equipment masjid (Figure 1), and the third is the training / simulation efficiency or energy saving in the use of the mosque (picture 2). Furthermore, the final reporting of events subsequent to the monitoring and evaluation of activities by LPM USU (figure 3).

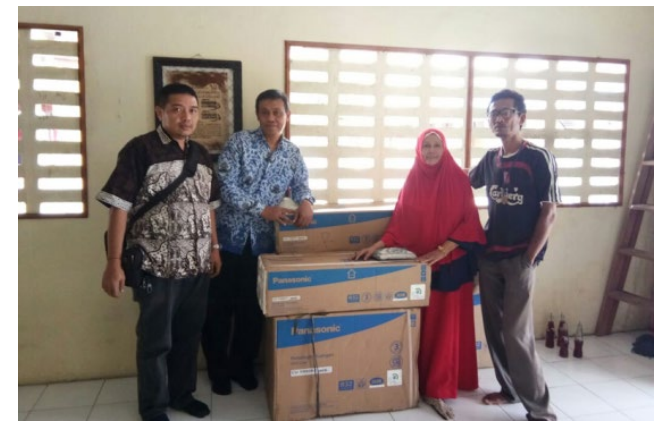

Figure 1. Handing over the equipment to Serikat Amal Baik Mosque.

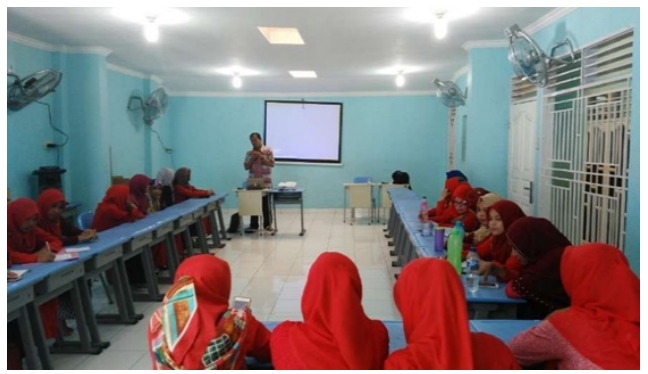

Figure 2. Training on energy saving in SDIT Zahira School

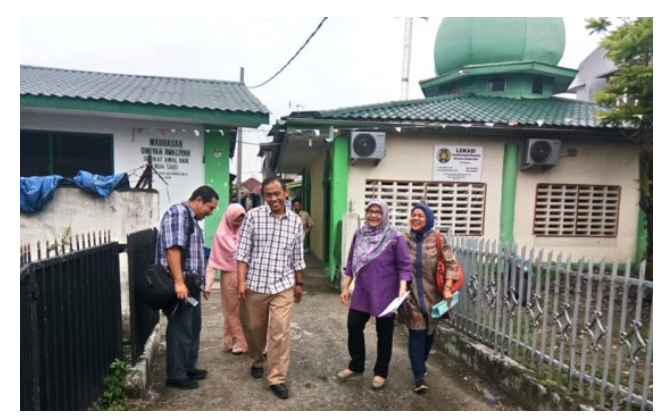

Figure 3. Monitoring and Evaluation LPM USU

\section{CONCLUSION}

From community service activities that have been carried out concluded that the targets and outcomes achieved with consideration for further improvement of infrastructure facilities in the existing mosque. Visible enthusiastic educators in the Islamic basic training as an energy-saving Islamic spiritual education development framework on an ongoing basis.

\section{ACKNOWLEDMENT}

Thanks to the Universitas Sumatera Utara through the Institute of Community Services (LPM USU), which provides financing this public service activities, entitled WORSHIP FACILITY IMPROVEMENT IN KELURAHAN SEI KERAH HILIR I 
Lindarto. et.al. Worship Facility Improvement In Kelurahan Sei Kerah Hilir I Kecamatan Medan Perjuangan, Kota Medan

KECAMATAN MEDAN PERJUANGAN, KOTA MEDAN. In accordance with the Letter of Assignment Agreement Implementation Community Service, Mono Year Scheme, NON PNBP, Fiscal Year 2018 No: 172 / UN5.2.3.2.1 / PPM / 2018, April 16, 2018.

\section{REFFERENCE}

[1] Ley, A., \& Newton, P. (2010). Creating and sustaining liveable cities. In Developing living cities: From analysis to action (pp. 191-229).

[2] BPS Sumatera (2017). Provinsi Sumatera Utara Dalam Angka 2016. Diakses dari http://sumut.bps.go.id.[05 Januari 2018]

[3] Issemiarti, S. M., \& Arsitektur, T. (2011). Revitalisasi Bangunan Lama sebagai Upaya Konservasi Kota.

[4]Syamsiyah, N. R. (2013). Kenyamanan Ruang dalam Masjid dan Pembentukan Generasi Islam.

[5] Mulyani, E. (2011). Model pendidikan kewirausahaan di pendidikan dasar dan menengah. Jurnal Ekonomi \& Pendidikan, 8(1).

[6] Moses, K. M., Muladi, M., \& Wibawa, A. P. (2017). The Linkage between Vocational Schools and Industries Cooperation a comparison in Developed and Developing Countries. In International Conference on Education (pp. 483-492).

[7] Syahra, R. (2003). Modal sosial: Konsep dan aplikasi. Jurnal Masyarakat dan Budaya, 5(1), 1-22.

[8] Sudibyo, R. P. (2006). Partisipasi masyarakat Sub Urban Dalam Pembangunan Kota Malang. Jurnal Humanity, 1(2).

[9] Saputra, A., \& Rochis, M. (2014). ADAPTATION STRATEGY OF MOSQUE ARCHITECTURE IN THE MINORITY
NEIGHBORHOOD. Journal of Islamic Architecture Volume, 3(2).

[10] Mediastica, C. E. (2013). Hemat Energi dan Lestari Lingkungan Melalui Bangunan (Doctoral dissertation, Penerbit ANDI Yogyakarta). 